\title{
Physical-mechanical Properties of Plywood Produced With Acrocarpus fraxinifolius and Pinus oocarpa
}

\author{
Abner Henrique Santos Reis ${ }^{1}$ (D), Danillo Wisky Silva ${ }^{1}$ (D), \\ Alan Pereira Vilela ${ }^{1}$ (D), Rafael Farinassi Mendes ${ }^{1}$ (D) Lourival Marin Mendes ${ }^{1}$ (D) \\ ${ }^{1}$ Universidade Federal de Lavras (UFLA), Lavras, MG, Brasil
}

\begin{abstract}
The present study has the objective of evaluating the physical-mechanical properties of plywood produced with Acrocarpus fraxinifolius wood, as well as the effect of combining their veneer with Pinus veneer. The wood of Acrocarpus fraxinifolius and Pinus oocarpa were used in the production of the panels. The plywood was produced with five veneers; the adhesive used was phenol-formaldehyde, weighing $320 \mathrm{~g} . \mathrm{m}^{-2}$. The evaluated properties were: equilibrium moisture (EM), specific mass (SM), water absorption (WA), thickness swelling (TS), shear strength (SS), modulus of rupture (MOR) and modulus of elasticity (MOE) both parallel and perpendicular to the fibers. No statistical difference was observed in the EM and TS, whereas all other properties showed statistical differentiation between the treatments. In general, the use of Acrocarpus fraxinifolius veneers improved the physical-mechanical properties of the compensated ones. Thus, the use of this species in the production of plywood is technically feasible.
\end{abstract}

Keywords: alternative species, Indian cedar, wood panels, technological properties. 


\section{INTRODUCTION AND OBJECTIVES}

In Brazil, current research on the use of fast-growing species in forest plantations for producing veneers and panels has been developed. In this field, the research seeks alternatives to Pinus, widely used in the plywood industries (Iwakiri et al., 2001).

Research on the genus Eucalyptus is already consistent, indicating the quality of this genus in the production of plywood panels (Almeida et al., 2004; Buddi et al., 2017; Buddi et al., 2015; Guimarães et al., 2012). Some authors, however, point to the use of different species for the production of slides and compensated ones. Some of these species are: Cryptomeria japonica (L. f.) (Pinto, 2011); Schizolobium parahyba Vell. Blake (Bortoletto \& Belini, 2002); Schizolobium amazonicum Huber ex. (Iwakiri et al., 2011); Sequoia sempervirens (Iwakiri et al., 2012); Toona ciliata M. Roem. Var. Australis (Albino et al., 2011), among others.

The Indian cedar (Acrocarpus fraxinifolius Wight \& Arn.), belonging to the Fabaceae family, subfamily Caesalpinioideae, is a native species from Asian tropical regions, common at altitudes varying from 0 to 2,000 meters, adaptable to regions with precipitation of $500 \mathrm{~mm}$ to $3,000 \mathrm{~mm}$ and average temperatures of $14{ }^{\circ} \mathrm{C}$ to $26^{\circ} \mathrm{C}$ (Martínez et al., 2006). In Brazil, the species presents an average annual increase of $14 \mathrm{~m}^{3}$ to $45 \mathrm{~m}^{3} / \mathrm{ha}$ /year, with the most suitable regions being: Southeast, Midwest and North of Paraná (Carvalho, 1998).

The hardwood of reddish heartwood of the Acrocarpus fraxinifolius species is used in furniture production, cellulosic pulp and paper production and civil construction (Honorato, 2005; Lorenzi et al., 2003; Orwa et al., 2009; Rocas, 2010). Another interesting aspect of this wood is its ease of processing and bonding, which has aroused researchers' interest in the production of particulate panels (Honorato, 2005; Iwakiri et al., 2014; Trianoski et al., 2011). However, there is little information on the use of this species in the production of plywood. In this context, the present study has the objective of evaluating the physical-mechanical properties of plywood produced with Acrocarpus fraxinifolius wood, as well as the effect of combining these veneers with Pinus oocarpa veneers.

\section{MATERIALS AND METHODS}

In this research, five trees of the species Acrocarpus fraxinifolius (20-year-old) and five trees of the species Pinus oocarpa (28-year-old) were used. They all came from experimental planting located in the municipality of Lavras-Minas Gerais (MG), Brazil, under the geographic coordinates $21^{\circ} 13^{\prime} 21^{\prime \prime} \mathrm{S}$ and $44^{\circ} 58^{\prime} 26^{\prime \prime} \mathrm{W}$, at an altitude of approximately $907 \mathrm{~m}$. The basic density of the two wood species was determined according to NBR 11,941 standard (ABNT, 2003).

In the processing of Acrocarpus fraxinifolius and Pinus oocarpa wood, the logs were sectioned into $55 \mathrm{~cm}$ long logs, which were then cooked in a tank for 24 hours at a temperature of $66^{\circ} \mathrm{C}\left( \pm 3^{\circ} \mathrm{C}\right.$ variation $)$. Then, the logs were rolled with a rolling mill to obtain $2 \mathrm{~mm}$ thick veneers. The veneers were guillotined in the final dimensions of $480 \mathrm{~mm} \times 480 \mathrm{~mm}$ and later partitioned in the horizontal plane for natural drying in a covered place for 48 hours.

The material was then oven dried with forced air circulation until it was obtained a final moisture of approximately $8 \%$. The veneers were classified in quality grades according to NBR 9531 standard (ABNT, $1986 \mathrm{~b}$ ), in which veneers classified as " $\mathrm{A}$ " and " $\mathrm{B}$ " were intended for the face and " $C$ " and " $D$ " for the panel core.

Plywoods were formed using five veneers perpendicularly disposed to each other, glued with 320 g. $\mathrm{m}^{-2}$ in double line of phenol-formaldehyde adhesive ( $\mathrm{pH}$ of 11.8 , solids content of $50.37 \%$, viscosity of $4,200 \mathrm{cP}$ ), process that included a ten-minute assemblage and an eight-minute pressing process, at a temperature of $160^{\circ} \mathrm{C}$ and pressure of $1.2 \mathrm{Mpa}$. Three panels were produced (replicates) per treatment, having a total of six treatments (Figure 1), in which only panels produced exclusively with Pinus or with Indian cedar were evaluated. In addition, different combinations of Indian cedar veneers with Pinus were also evaluated.

The panels were stored in a conditioned environment with relative humidity of $65 \%$ ( $\pm 3 \%$ variation) and temperature of $20^{\circ} \mathrm{C}\left( \pm 2^{\circ} \mathrm{C}\right.$ variation). Subsequently, the specimens were cut for evaluation of the following properties: specific mass (SM), according to standard NBR 9485 (ABNT, 1986a); water absorption (WA), according to standard NBR 9484 (ABNT, 1986d); thickness swelling (TS), according to standard NBR 9535 (ABNT, 1986c); modulus of rupture (MOR) and 


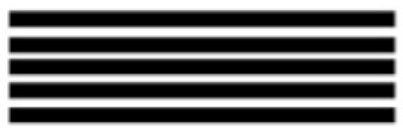

$5 A f^{*}$

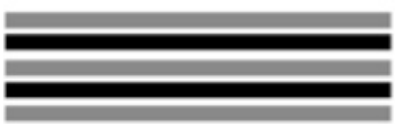

$3 P 0 \_2 A f$

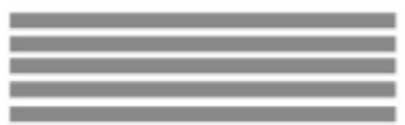

$5 P 0^{* *}$

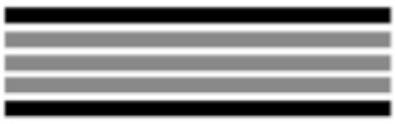

$$
A f_{\text {face_e }} P \mathrm{O}_{\text {core }}
$$

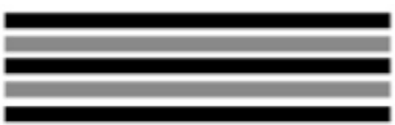

$3 A f \_P O$

Acrocarpus fraxinifolius ${ }^{*}$

Pinus oocarpa **

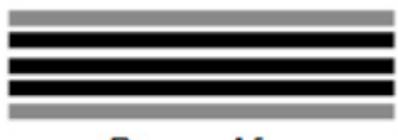

$$
P \mathrm{O}_{\text {face_}} A f_{\text {core }}
$$

Figure 1. Experimental plan. Af: Acrocarpus fraxinifolius; Po: Pinus oocarpa.

modulus of elasticity (MOE) were obtained according to standard EN 310 (ECS, 1993a); and shear strength (SS) in the glue line under dry and humid conditions, according to standard EN 314 (ECS, 1993b).

The analysis of the results was executed through a completely randomized design. To evaluate the effect of the different treatments on the physical-mechanical properties of the panels, the results were submitted to analysis of variance and Scott-Knott mean test, both at $5 \%$ significance level.

\section{RESULTS AND DISCUSSION}

\subsection{Physical properties of plywood}

The mean values of the basic wood density of Acrocarpus fraxinifolius and Pinus oocarpa woods were $520 \mathrm{~kg} \cdot \mathrm{m}^{-3}\left( \pm 19 \mathrm{~kg} \cdot \mathrm{m}^{-3}\right.$ variation $)$ and $410 \mathrm{~kg} \cdot \mathrm{m}^{-3}$ ( $\pm 22 \mathrm{~kg} \cdot \mathrm{m}^{-3}$ variation), respectively. The observed variation refers to the difference between the species in the number of vessels per area, cell wall diameter, and anatomical arrangement among other aspects inherent to the anatomy of the wood. The values observed are consistent with the ranges reported in the literature for Acrocarpus fraxinifolius, in which values varying from $440 \mathrm{~kg} . \mathrm{m}^{-3}$ to $680 \mathrm{~kg} . \mathrm{m}^{-3}$ were observed for 20 -year-old trees (Carvalho, 1998; Honorato, 2005; Prado et al., 2003; Simpson, 1996). The value observed for Pinus oocarpa wood is also consistent with the literature in which values varying from $393 \mathrm{~kg} \cdot \mathrm{m}^{-3}$ to $564 \mathrm{~kg} \cdot \mathrm{m}^{-3}$ for 13-year-old trees are reported (Amaral et al., 1977). Although the species had different basic densities, it was not necessary to change the heating time of the logs. Besides, the knives and counter-knives of the rolling mill showed no visible damage and the quality of the wood veneers for both species were visually similar.

The specific mass properties - moisture, WA and TS - for the different compensated panels evaluated are presented in Table 1. There was variation between the different treatments for the specific mass properties and WA. However, for the moisture and TS properties, no difference was observed between the different types of panels.

The TS values for the different panels were lower than those reported by Mendes et al. (2013). Evaluating the effect of different types of chemical treatments on Pinus taeda wood for plywood production, the authors found values of TS varying from $7.84 \%$ to $8.37 \%$.

The highest specific mass value was observed in panels with five Indian cedar veneers, whereas the lowest one was seen in panels with five veneers Pinus. When the other panels were evaluated, the treatment with three veneers of Indian cedar in the core of the panel obtained specific mass greater than the other associations.

The panels made only with Acrocarpus fraxinifolius are denser than the other panels, because the basic density of their wood is greater than that of Pinus, and the panels are produced with the same dimensions (volume); however, the difference observed between 
Table 1. Specific mass, moisture, water absorption (WA) and thickness swelling (TS) for the plywood.

\begin{tabular}{|c|c|c|c|c|}
\hline \multirow{2}{*}{ Treatment } & Specific mass & Moisture & WA & TS \\
\hline & $\left(\mathrm{kg} \cdot \mathrm{m}^{-3}\right)$ & \multicolumn{3}{|c|}{ (\%) } \\
\hline $5 A f$ & $726.7^{(34.3)^{*}} \mathrm{~d}$ & $9.04^{(0.07)^{*}} \mathrm{a}$ & $50.5^{(0.9)^{*}} \mathrm{a}$ & $5.62^{(0.06)^{*}} \mathrm{a}$ \\
\hline $5 \mathrm{Po}$ & $513.3^{(27.0)} \mathrm{a}$ & $10.23^{(0.10)} \mathrm{a}$ & $65.7^{(1.2)} \mathrm{b}$ & $5.66^{(0.09)} \mathrm{a}$ \\
\hline $3 A f \_2 P o$ & $626.7^{(7.8)} \mathrm{b}$ & $9.36^{(0.11)} \mathrm{a}$ & $61.3^{(1.2)} \mathrm{b}$ & $6.27^{(0.11)} \mathrm{a}$ \\
\hline 3 Po_2 Af & $590.0^{(9.0)} \mathrm{b}$ & $9.74^{(0.13)} \mathrm{a}$ & $63.7^{(1.1)} \mathrm{b}$ & $6.08^{(0.14)} \mathrm{a}$ \\
\hline$A f_{\text {face }} P o_{\text {core }}$ & $593.3^{(32.6)} \mathrm{b}$ & $9.55^{(0.08)} \mathrm{a}$ & $63.1^{(1.9)} \mathrm{b}$ & $6.04^{(0.07)} \mathrm{a}$ \\
\hline$P o_{\text {face }} A f_{\text {core }}$ & $670.0^{(18.2)} \mathrm{c}$ & $9.42^{(0.09)} \mathrm{a}$ & $53.6^{(1.4)} \mathrm{a}$ & $5.43^{(0.08)} \mathrm{a}$ \\
\hline
\end{tabular}

Means followed by the same letter in the column do not differ statistically from one another by the Scott-Knott test, at $5 \%$ significance. ${ }^{\star}$ The values in parentheses correspond to the standard deviation. Af: Acrocarpus fraxinifolius; Po: Pinus oocarpa.

the panels constituted with the different associations of Indian cedar and Pinus can be explained by the glue line. Due to the lower density of the pine wood, the veneers tend to absorb more adhesive material, being able to form a starved glue line (Baldwin, 1993; Marra, 1992; Sellers, 1993), impairing the dimensional stability of the panels. Another aspect observed by Trianoski et al. (2013) is that Pinus wood has more acidic pH than that of Indian cedar wood, which may hinder the polymerization of phenol-formaldehyde (Marra, 1992), and consequently release possible rates of return of the veneers after pressing, which also helps to understand the difference between the specific masses observed between the veneers associations evaluated in this study.

With respect to the water absorption property, it was observed that the panels with five and three veneers (in the core) of Acrocarpus fraxinifolius obtained the lowest absorption. These results show the higher bonding efficiency of the cedar veneers compared to the pine veneers, indicating the influence of the basic density, porosity and $\mathrm{pH}$ on the adhesion of the veneers.
The addition of Acrocarpus fraxinifolius veneers increased the specific mass and decreased the WA of the plywood panels. In the use of the Acrocarpus fraxinifolius veneers intercalated with Pinus oocarpa, the specific mass decreases and the WA increases, indicating a negative interaction, or even showing the best adhesion quality of the wood of Acrocarpus fraxinifolius.

\subsection{Mechanical properties}

There was a difference between the plywood evaluated in this study for the modulus of rupture (MOR) and modulus of elasticity (MOE) for the static bending in the parallel $(\|)$ and perpendicular $(\perp)$ direction and in the shear strength (SS) in the glue line under the dry and wet conditions, as shown in Table 2 .

The panels with five Indian cedar veneers showed the best results for MOR and MOE in the parallel direction and also the best results for dry and wet SS. The increase of the cedar veneers improves the mechanical properties

Table 2. Modulus of rupture (MOR) and modulus of elasticity (MOE) with static bending in the parallel (\|) and perpendicular $(\perp)$ direction, and shear strength (SS) in the glue line in dry and wet conditions (for the plywood).

\begin{tabular}{|c|c|c|c|c|c|c|}
\hline \multirow{2}{*}{ Treatment } & MOR ॥ & MOE ॥ & MOR ^ & $\mathrm{MOE} \perp$ & $\mathrm{SS}_{\mathrm{dry}}$ & SS $_{\text {wet }}$ \\
\hline & \multicolumn{6}{|c|}{ (Mpa) } \\
\hline $5 A f$ & $96.8^{(8.7)^{*}} \mathrm{~b}$ & $8496^{(795)} \mathrm{c}$ & $49.4^{(5.1)} \mathrm{b}$ & $2709^{(475)} \mathrm{b}$ & $9.0^{(1.1)} \mathrm{d}$ & $7.04^{(1.0)} \mathrm{c}$ \\
\hline $5 P o$ & $56.8^{(9.6)} \mathrm{a}$ & $4912^{(588)} \mathrm{a}$ & $31.5^{(1.9)} \mathrm{a}$ & $1808^{(195)} \mathrm{a}$ & $3.1^{(1.4)} \mathrm{a}$ & $2.1^{(0.1)} \mathrm{a}$ \\
\hline $3 A f \_2 P o$ & $71.6^{(11.0)} \mathrm{a}$ & $7654^{(880)} \mathrm{c}$ & $40.2^{(12.4)} \mathrm{a}$ & $1854^{(110)} \mathrm{a}$ & $5.2^{(1.7)} \mathrm{b}$ & $3.3^{(0.7)} \mathrm{a}$ \\
\hline 3 Po_2 Af & $67.7^{(5.1)} \mathrm{a}$ & $6594^{(286)} \mathrm{b}$ & $41.7^{(2.5)} \mathrm{a}$ & $2350^{(177)} \mathrm{a}$ & $3.1^{(0.5)} \mathrm{a}$ & $2.9^{(0.5)} \mathrm{a}$ \\
\hline$A f_{\text {face- }} P o_{\text {core }}$ & $74.1^{(7.3)} \mathrm{a}$ & $7831^{(574)} \mathrm{c}$ & $43.5^{(13.8)} \mathrm{a}$ & $3007^{(334)} \mathrm{b}$ & $2.9^{(0.5)} \mathrm{a}$ & $2.7^{(0.5)} \mathrm{a}$ \\
\hline$P o_{\text {face }} A f_{\text {core }}$ & $71.8^{(10.8)} \mathrm{a}$ & $6403^{(786)} \mathrm{b}$ & $54.3^{(2.6)} \mathrm{b}$ & $3019^{(160)} \mathrm{b}$ & $6.2^{(1.8)} \mathrm{c}$ & $5.0^{(0.6)} \mathrm{b}$ \\
\hline
\end{tabular}

Means followed by the same letter in the column do not differ statistically from one another by the Scott-Knott test, at $5 \%$ significance. ${ }^{\star}$ The values in parentheses correspond to the standard deviation. Af: Acrocarpus fraxinifolius; Po: Pinus oocarpa. 
due to the higher basic density of the cedar, since, in general, this property has a positive correlation with the mechanical properties of the wood (Nisgoski et al., 2012). The variations observed in the properties of the panels with three cedar veneers in different positions for the MOE parallel to the fibers are related to the position of the fibers in the Indian cedar veneers, once these veneers are more resistant and rigid than the veneers of pine. The variation in SS, on the other hand, can be explained by the higher number of pores and the lower pH of the pine wood (Trianoski et al., 2013), impairing the quality of the bonding of the panels. However, it is noteworthy that both panels produced in this study obtained good SS in the glue line.

The panels with five cedar veneers (5Af), with three pine veneers interspersed with two cedar (3Po_2Af), with the cedar face veneers $\left(A f_{\text {face }} P o_{\text {core }}\right)$ and with three cedar veneers inside the panel $\left(P o_{\text {face- }} A f_{\text {core }}\right)$ complied with all requirements of Abimci (2007) for Pinus panels for external structural use, which requires minimum values of $28.05 \mathrm{MPa}$ and $22.08 \mathrm{MPa}$ for MOR in the parallel and perpendicular direction, respectively; and 3,275 MPa and 2,169 MPa for the MOE in the parallel and perpendicular direction, respectively.

All treatments evaluated in this study obtained SS in dry and wet conditions higher than $1 \mathrm{MPa}$, according to technical standard. The percentage of failure in SS in dry and wet conditions, respectively, was not presented, because the guidelines of standard EN 314.2 (ECS, 1993c) indicate that in cases of rupture voltages equal to or greater than $1 \mathrm{MPa}$, the failure percentage of wood can be neglected.

In general, the use of Indian cedar in the production of plywood panels is viable. Indian cedar also has technological properties intrinsic to its wood that lead to significant improvements in WA, MOR, MOE and SS properties compared to pine panels. Due to specific laboratory conditions, which do not always reproduce the industrial process, panels with five Pinus blades did not meet the technical standard requirements for plywood panels intended for civil construction.

\section{CONCLUSIONS}

The difference between the basic densities of the two species did not interfere in the heating time of the logs, nor was there any damage in the knife and counter-knife of the rolling mill or in the quality of the veneers produced. In general, plywood produced with five Indian cedar veneers presented lower values of WA and higher values of MOR, MOE and SS, However, the association of cedar and Pinus veneers also showed an improvement in the mechanical properties evaluated.

The species Acrocarpus fraxinifolius can be used in the production of compensated panels of structural use, or even in association with other species, in order to improve the physical-mechanical properties of the panels. New studies that seek to increase knowledge about the intrinsic mechanisms of cedar wood that positively affect the bonding of the veneers are relevant.

\section{ACKNOWLEDGEMENTS}

To Rede Brasileira de Compósitos e Nanocompósitos Lignocelulósicos (Religar).

\section{SUBMISSION STATUS}

Submitted: 15 Feb., 2017

Accepted: 24 Jan., 2018

\section{CORRESPONDENCE TO}

\section{Danillo Wisky Silva}

Universidade Federal de Lavras (UFLA), Rua Silvio Modesto de Souza, 492, CEP 37200-000, Lavras, MG, Brasil e-mail: danilowisky@hotmail.com

\section{FINANCIAL SUPPORT}

Fundação de Amparo à Pesquisa do Estado de Minas Gerais (Fapemig), Conselho Nacional de Desenvolvimento Científico e Tecnológico (CNPq), and Coordenação de Aperfeiçoamento de Pessoal de Nível Superior (Capes).

\section{REFERENCES}

Albino VCS, Sá VA, Bufalino L, Mendes LM, Almeida NA. Avaliação das propriedades físico-mecânicas de painéis compensados de Toona ciliata M. Roem. var. australis. Cerne 2011; 17(1): 103-108. 10.1590/S010477602011000100012 
Almeida RR, Bortoletto G Jr, Jankowsky IP. Produção de lâminas a partir da madeira de clones do híbrido Eucalyptus grandis $\times$ Eucalyptus urophylla. Scientia Forestalis 2004; (65): 49-58.

Amaral AC, Ferreira M, Couto HTZ. Métodos de avaliação da densidade básica da madeira de populações de pinheiros tropicais. IPEF 1977; (15): 47-67.

Associação Brasileira da Indústria de Madeira Processada Mecanicamente - Abimci. Abimci: painéis compensados de pinus. Curitiba: Editora da Abimci; 2007. (Catálogo Técnico 2)

Associação Brasileira de Normas Técnicas - ABNT. NBR9485: chapas de madeira compensada: determinação da massa específica aparente. Rio de Janeiro; 1986a.

Associação Brasileira de Normas Técnicas - ABNT. NBR9531: chapas de madeira compensada: classificação. Rio de Janeiro; 1986b.

Associação Brasileira de Normas Técnicas - ABNT. NBR9535: chapas de madeira compensada: determinação do inchamento. Rio de Janeiro; 1986c.

Associação Brasileira de Normas Técnicas - ABNT. NBR9484: painéis de madeira compensada: determinação do teor de umidade. Rio de Janeiro; 1986d.

Associação Brasileira de Normas Técnicas - ABNT. NBR11941: madeira: determinação da densidade básica. Rio de Janeiro; 2003.

Baldwin RF. Plywood and veneer-based products: manufacturing practices. San Francisco: Miller Freeman; 1993.

Bortoletto G Jr, Belini UL. Produção de lâminas e manufatura de compensados a partir da madeira de guapuruvu (Schizolobium parahyba Blake) proveniente de um plantio misto de espécies nativas. Cerne 2002; 8(2): 1-16. $10.5902 / 1980509832089$

Buddi T, Mahesh K, Muttil N, Rao BN, Nagalakshmi J, Singh SK. Characterization of plywood produced by various bioadhesives. Materials Today: Proceedings 2017; 4: 496-508. 10.1016/j.matpr.2017.01.050

Buddi T, Muttil N, Rao BN, Singh SK. Development of a soya based adhesive in plywood manufacturing. Materials Today: Proceedings 2015; 2: 3027-3031. 10.1016/j.matpr.2015.07.289

Carvalho PE. Espécies introduzidas alternativas às do gênero Pinus e Eucalyptus para reflorestamento no Centro-Sul do Brasil. In: Galvão APM, coordenador. Espécies não tradicionais para plantios com finalidades produtivas $e$ ambientais. Colombo: Embrapa Florestas; 1998. p. 74-99.

European Committee for Standardization - ECS. EN-310: wood-based panels: determination of modulus of elasticity in bending streng. Brussels; 1993a.

European Committee for Standardization - ECS. EN314-1: plywood: bonding quality: part 1: test methods. Brussels; 1993b.
European Committee for Standardization - ECS. EN314-2: plywood. bonding quality. part 2: requirements. Brussels; 1993c.

Guimarães JB Jr, Mendes LM, Mendes RF, Guimarães BMR, Oliveira SL. Seleção de clones de Eucalyptus urophylla para produção de compensados. Cerne 2012; 18(4): 667-673. 10.1590/S0104-77602012000400017

Honorato SJA. Cedro rosado (Acrocarpus fraxinifolius) una opción agroforestal para la sierra Norte del estado de Puebla. Ciudad de México: Inifap, 2005. v. 1.

Iwakiri S, Cunha AB, Prata JG, Braz RL, Castro VG, Kazmierczak $S$ et al. Produção de painéis compensados com lâminas de madeira de Sequoia sempervirens e resina ureia-formaldeído. Floresta 2012; 42(4): 809-816. 10.5380/ rf.v42i 4.25688

Iwakiri S, Olandoski DP, Leonhardt G, Brand MAA. Produção de chapas de madeira compensada de cinco espécies de pinus tropicais. Ciência Florestal 2001; 11(2): 71-77. 10.5902/198050981656

Iwakiri S, Potulski DC, Sanches FG, Silva JB, Trianoski R, Pretko WC. Avaliação do potencial de uso da madeira de Acrocarpus fraxinifolius, Grevilea robusta, Melia azedarach e Toona ciliata para produção de painéis OSB. Cerne 2014; 20(2): 277-284. 10.1590/01047760.201420021201

Iwakiri S, Vargas CA, Parchen CFA, Weber C, Batista CC, Garbe EA et al. Avaliação da qualidade de painéis compensados produzidos com lâminas de madeira de Schizolobium amazonicum. Floresta 2011; 41(3): 451-458. 10.5380/rf.v41i3.23991

Lorenzi H, Souza HM, Torres MAV, Bacher LB. Árvores exóticas no Brasil: madeireiras, ornamentais e aromáticas. Nova Odessa, SP: Instituto Plantarum; 2003.

Marra AA. Technology of wood bonding: principles in practice. New York: V. N. Reinhold; 1992.

Martínez PE, García JMM, Sánches LH, Pérez GO. Cultivo intercalado de cedro rosado y su efecto sobre el contenido de materia orgánica en suelo. Revista UDO Agrícola 2006; 6(1): 109-113.

Mendes RF, Bortoletto G Jr, Vidal JM, Almeida NF, Jankowsky IP. Efeito do tratamento preservativo de painéis compensados sobre as suas propriedades físicomecânicas. Scientia Forestalis 2013; 41(100): 507-513. $10.5902 / 1980509831585$

Nisgoski S, Trianoski R, Muñiz GIB, Matos JLM, Stygar M. Variação radial das estruturas da Madeira de Acrocarpus fraxinifolius Wight \& Arn. Floresta e Ambiente 2012; 19: 316-324. 10.4322/floram.2012.037

Orwa C, Mutua A, Kindt R, Jamnadass R, Simons A. Agroforestree database: a tree reference and selection guide version 4.0. 2009 [cited 2017 Jan. 20]. Available from: https://bit.ly/2YQPTA1

Pinto JA. Análise da viabilidade do uso da madeira de Cryptomeria japônica para laminação e produção de painéis 
compensados [thesis]. Curitiba: Universidade Federal do Paraná; 2011.

Prado CA, Pereira JCD, Mattos PP, Schaitza EG, Higa AR. Características físicas e químicas da madeira de Acrocarpus fraxinifolius Wight \& Arn. Colombo: Embrapa Florestas; 2003. (Boletim de Pesquisa e Desenvolvimento, n. 14).

Rocas AN. Part II: Species Descriptions: Acrocarpus fraxinifolius Wight \& Arn. Xalapa: Instituto de Ecología; 2010.

Sellers T. Plywood and adhesive technology. New York: Marcel Dekker; 1993.
Simpson WT. Method to estimate dry-kiln schedules and species groupings: tropical and temperate hardwoods. Madison: U.S. Department of Agriculture, Forest Service, Forest Products Laboratory; 1996.

Trianoski R, Iwakiri S, Matos JLM, Prata JG. Viabilidade da utilização de Acrocarpus fraxinifolius sem diferentes proporções com Pinus spp. para produção de painéis aglomerados. Scientia Forestalis 2011; 39(91): 343-350.

Trianoski R, Iwakiri S, Matos JLM, Prata JG. Propriedades físicas e mecânicas de painéis de madeira aglomerada de Acrocarpus fraxinifolius, compostos com diferentes percentuais de casca. Ciência Florestal 2013; 23(4): 761-769. $10.5902 / 1980509812360$ 